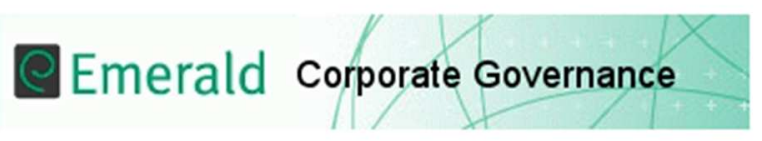

\title{
Corporate governance and greenhouse gas disclosure: A mixed-methods approach
}

\begin{tabular}{|r|l|}
\hline Journal: & Corporate Governance \\
\hline Manuscript ID & CG-10-2016-0202.R1 \\
\hline Manuscript Type: & Original Article \\
\hline Keywords: & $\begin{array}{l}\text { Corporate Governance, greenhouse gas, Disclosure, mixed-methods } \\
\text { approach, UK }\end{array}$ \\
\hline \multicolumn{2}{|l}{} \\
\hline
\end{tabular}

SCHOLARONE ${ }^{m}$

Manuscripts 


\title{
Corporate governance and greenhouse gas disclosure:
}

\author{
A mixed-methods approach
}

\begin{abstract}
Purpose

This paper investigates whether four corporate governance mechanisms (board size, nonexecutive directors, ownership concentration and directors' share ownership) influence the extent of greenhouse gas (GHG) disclosure.

\section{Design/Methodology/Approach}

The study uses a mixed-methods approach based on a sample of 62 FTSE 1000 firms. Firstly, we surveyed the senior management of 62 UK listed firms in the FTSE 1000 index to determine whether the corporate governance mechanisms influence their greenhouse gas GHG disclosure decisions. Secondly, we used Ordinary Least Squares (OLS) regression to model the relationship between the corporate governance mechanisms and GHG disclosure scores of the 62 firms.
\end{abstract}

\section{Findings}

The survey and OLS regression results both suggest that corporate governance mechanisms (board size and NEDs) do not influence GHG disclosures. However, the results of the two approaches differ in that the survey results suggest that corporate governance mechanisms (ownership concentration and directors' share ownership) do not influence the extent of GHG disclosure while the opposite is true with the OLS regression results.

\section{Research limitations/implications}

The sample size of 62 firms is small which could affect the generalisability of the study. The mixed results mean that more mixed method approach is needed to improve our understanding of the role of corporate governance in GHG disclosures.

\section{Originality/Value}

The use of mixed-methods to examine whether corporate governance mechanisms determine the extent of GHG voluntary disclosure provides additional insights not provided in prior studies.

\section{Paper Type Research Paper}

\section{Keywords}

Corporate governance, greenhouse gas, disclosure, mixed-methods approach, UK 


\section{Introduction}

Literature on the influence of corporate governance mechanisms on greenhouse gas voluntary disclosure decisions is growing (e.g., Prado-Lorenzo and Garcia-Sanchez, 2010; Galbreath, 2010; Peters and Romi, 2012, Tauringana and Chithambo, 2015). However, the mixed findings (e.g, Berthelotand Robert, 2011; Peters and Romi, 2012; Rankin, Windsor and Wahyuni, 2011; Michelon and Parbonetti, 2012) led to calls for the use of the qualitative research approach in addition to the predominantly quantitative approach in the form of ordinary least squares (OLS) regression to improve our understanding of the determinants of extent of disclosure (e.g., Beattie and Smith, 2012; Michelon and Parbonetti, 2012). For example, Beattie and Smith (2012) noted that primary research based disclosure studies are rare, yet such a research approach could bring enormous benefits to the understanding of the motives for disclosure. This is because investigating the determinants of disclosure using the quantitative approach is inadequate because there are other internal contextual factors that may affect disclosure (Adams, 2002; Gray, Javad, Power and Sinclair, 2001).

The objective of this paper is to investigate whether corporate governance mechanisms (board size, non-executive directors, ownership concentration and directors' share ownership) influence the extent of GHG disclosures using mixed method. To achieve this objective, the study surveyed 62 firms derived from the largest 1000 companies listed on the London Stock Exchange main market to determine whether corporate governance mechanisms influence extent of GHG disclosure. This was followed by the use of the research index methodology to measure the extent of GHG disclosures in annual reports, sustainability reports and websites of the 62 firms. The extent of GHG disclosure was then regressed against corporate governance mechanisms (controlling for size, profitability, leverage and liquidity) to determine whether there was any association. 
This paper makes two contributions to existing literature. First, it adds to existing literature by responding to calls to fill the gap of the research into the effect of corporate governance mechanisms on voluntary disclosure using the qualitative approach (e.g., Michelon and Parbonetti, 2012, Beattie and Smith, 2012). Specifically, the paper contributes to the dearth of evidence on the efficacy of corporate governance mechanisms on GHG disclosure using qualitative data. Second, by using the mixed method approach, the study also contributes by providing evidence of how the results of the quantitative approach compares with those of the qualitative approach. According to Johnson et al. (2007, p. 113), '..the primary philosophy of mixed research is that of pragmatism. Mixed methods research is an approach to knowledge (theory and practice) that attempts to consider multiple viewpoints, perspectives, positions, and standpoints (always including the standpoints of qualitative and quantitative research'. Since existing research results are in many cases based on quantitative approaches only, there is a gap in our knowledge as to how research results using the qualitative and quantitative approaches compare. To our knowledge we are not aware of any other study that has adopted such a research design in investigating how corporate governance may impact the extent of GHG disclosure hence our study makes a contribution to both environmental disclosure studies and GHG disclosure studies.

The remainder of the paper is organised as follows - Section 2 discusses the theoretical frameworks relating to corporate governance and GHG voluntary disclosure, and this leads to hypotheses development. Section 3 discusses the research methodology. Section 4 discusses the findings, and the final section is a summary and conclusion.

\section{Literature review and hypotheses development}

\subsection{Literature Review}


Agency theory underpins most of the studies investigating the role of corporate governance mechanisms on voluntary disclosures. Agency theory conceptualised by Jensen and Meckling (1976) provides a basis or justification on which governance mechanisms are put in place to resolve conflict of interest or incentive problems brought by the modern form of corporation in which ownership is diversified from management (Donnelly and Mulcahy, 2008). Separation of ownership and control often leads to information asymmetries which if not checked are exploited by managers for their own benefit at the expense of the shareholders (Jensen and Meckling, 1976). Thus corporate governance mechanisms serve as protectors of shareholder interests amidst competing interests by various stakeholders of the firm (Kumar and Zattoni, 2013). Since at the heart of the agency relationship between managers and owners is an issue of information asymmetry, prior literature has documented evidence that corporate governance mechanisms help improve corporate disclosure as a way of minimising the information asymmetry gap (Chen and Jaggi, 2000; Peasnell, Pope and Young, 2005; Rankin et al., 2011; Mangena and Tauringana, 2007). Therefore, in theory, corporate governance mechanisms should assist in aligning managers' interests to those of the institution and so reduce agency costs in the long term.

Literature has identified a number of corporate governance characteristics that help influence voluntary disclosures. These include board composition and size, the presence of non-executive directors, CEO duality, audit committee and audit firm. Beasley, Carcello, Hermanson, and Lapides (2000) found the presence of non-executive directors on the board to be crucial in preventing management fraud thereby protecting shareholder interests. The board of directors are also meant to champion transparency and accountability which is essential in disclosures (Collier and Zaman, 2005). Studies on GHG disclosures particularly focusing on corporate governance characteristics have included Prado-Lorenzo and GarciaSanchez (2010) who investigated the role of board of directors in divulging relevant GHG 
information in a sample of FTSE Global 500 companies which participated in the CDP 2008 survey. The disclosure index was developed from the Carbon Disclosure Leadership Index (CDLI). Their results partly indicated that though firms are under public pressure to disclose GHG information, the board of directors sometimes discourages these disclosures if there is high probability of litigation i.e. more especially when the costs of disclosure outweighs the benefits. Their results also suggested that while the business environment has changed over time with the influence of other stakeholders increasing, as far as climate change related information is concerned, the board has continued to maintain the tradition of prioritising shareholder interests.

In another study focusing on which attributes of corporate governance influences a firm to make GHG disclosures, Peters and Romi (2012) examined the determinants of GHG voluntary reporting in a sample of firms participating in the CDP from 2002-2006 and found evidence that GHG disclosures were positively related to what they called 'sustainability oriented corporate governance characteristics notably the presence of environmental committee on board as well as the position of corporate sustainability officers. Expertise and size of the board members and sustainability officers were dominant characteristics of those firms that disclosed more GHG information. Knowledge synergies between environmental committee and the audit committee were also found to be a significant element in increasing the likelihood of voluntary GHG disclosures. Galbrealth (2010) investigated how well governance structures by both US and non-US firms had enabled the firms to respond to climate change challenge using 98 firms in three industries across ten countries. Overall they found that the firms were underperforming in their governance responses towards climate change but noted that non-US firms had a better governance score than their US counterparts using the Ceres scoring methodology. In addition, board characteristics such as board size, and diversity (including female representation) had no statistical link to climate change 
disclosures, while directors' age had some influence with younger directors exerting positive influence.

\subsection{Hypotheses development \\ Board size}

The board of directors, instituted as a mechanism to resolve the agency problem, has over the period seen their role increasingly becoming champions of communication between management and a firm's various stakeholders (Rupley, Brownand Marshall, 2012; Kolk and Pinkse, 2010; Monks and Monow, 2004). Prior researchers have argued that the way a board is structured affects the way it discharges its responsibility (Galbrealth, 2010; Rodrigue et al., 2012). Based on significant progress made in corporate governance area, listed companies in the UK are expected to institute some governance structures or explain their failure to do so (Financial Reporting Council, 2016). Large numbers of board members which represent various shareholder interests may in a way help reduce information asymmetry (Chenand Jaggi, 2000). The main function of the board is to formulate policies and strategies to be implemented by management.

In discharging their role, the board is aware that information is an important link to its outsiders as such it may champion policies that encourage more disclosures. The large number of board members is likely to make the board function effectively in ensuring that policies and strategies are implemented (Zahra, Neubaum and Huse, 2000). A large board is also likely to have diverse experience and skills that may be crucial in assisting management in the processing and disclosing of useful information (Akhtarudin, Hossain, Hossain and Yao, 2009). Empirical studies have found evidence of the influence of large sized board to disclosures. Peters and Romi (2012) noted that in addition to other board attributes, those firms with a large board size had more GHG disclosures. Similarly, Cormier, Gordon, 
Magnan and Aerts (2010) found a positive association of large board size and disclosures. That study investigated whether environmental disclosures substitutes or compliments efforts in reducing information asymmetry between corporate managers and stock market analysts on a sample of 137 large Canadian companies listed on the Toronto Stock Exchange in 2005. Their environmental disclosure score was weighted with a high score awarded if disclosures are quantitative and specific than qualitative and general. The results among other factors, found that board size was the only board characteristic that had a significant positive relationship with environmental disclosures. Others like Michelon and Parbonetti (2012) did not find any association. Given that there are both arguments for expecting a positive and a negative relationship, no prediction of the sign of the relation is predicted. It is therefore hypothesised that:

$H_{1}$ : There is a significant relationship between board size and GHG information disclosure.

Non-executive directors

The presence of non-executive directors (NEDs) is one indication of the level of board independence (Prado-Lorenzo and Garcia-Sanchez., 2010). Arguably, the presence of non-executive directors helps the board discharge its monitoring responsibilities effectively (Fama and Jensen, 1983; Akhtarudin et al., 2009). According to provision B1.2 of the Financial Reporting Council (2016), companies in the UK are encouraged to have more nonexecutive directors than executive directors on their boards as a way of enhancing board independence and improving board efficiency. It is intimated that board members with no material interest in the company are able to act both in the interests of shareholders and other legitimate stakeholders of the company. Thus, from a stakeholder theory perspective, independent non-executive directors who represent the interests of other stakeholders other than management are viewed as a tool for monitoring management behaviour (Dixon, Milton and Woodhead, 2005). Such monitoring, from the perspective of agency theory, helps to 
minimise the principal-agency problem that exists between shareholders and management. Forker (1992) found evidence that increased numbers on NEDs on the board had led to increased quality of financial disclosures. However in the study by Ho and Wong (2001) for Hong Kong listed companies, the positive hypothesis was not supported. Post, Rahman, and Rubow (2011) found a positive relationship between presence of NEDs and environmental disclosures while the study of Brammer and Pavelin (2006) focusing on UK companies' environmental disclosures did not find any association. However considering the uncertainty surrounding GHG matters, the presence of more NEDs on the board is likely to help a firm keep pace with the dynamics of climate change and of the action needed. The presence of more outside directors may also force or persuade firm management to be more transparent about its role in climate change which then may lead to more disclosures on GHG information. In view of this therefore we state the hypothesis as follows:

$H_{2}$ : There is a positive relationship between the proportion of NEDs on the board and GHG information disclosure.

\section{Ownership concentration}

Separation of ownership from control often leads to information asymmetries which if not checked are exploited by managers for their own benefit at the expense of shareholders (Jensen and Meckling, 1976). Thus ownership structure is considered part of the governance structure that helps monitor managerial behaviour. Nonetheless monitoring becomes difficult when ownership is dispersed due to 'free rider' problem as such managers taking advantage and having great discretion which could be used for their own benefit at the expense of others. It is argued that large block holding (or high concentration of ownership) means that stakes are high should management mess up things or act irrationally, and the owners are expected to have resources and special interest in monitoring management behaviour 
(Shleifer and Vishny, 1986; Noe, 2002). Shleifer and Vishny (1986) argued that large block holders often with a large resource base are likely to absorb monitoring costs than individual holders. Besides, as agency theory suggests, monitoring has costs which may eventually be passed on to managers through contractual arrangements with high ownership concentration and management may have the incentives to disclose more information as way of minimising the information asymmetry. Berthelot and Robert (2012) found a positive relationship between widely held ownership and voluntary disclosures of climate change information by Canadian oil and Gas companies. Matolcsy, Shan and Seethamraju (2012) found that high concentration of ownership (represented by the percentage of shares owned by top twenty shareholders) had a negative association with disclosures. Similarly, Brammer and Pavelin (2008) found that firms with high ownership concentration in the UK had fewer disclosures of environmental information of good quantity and quality. However there is also evidence to the contrary. Haniffa and Cooke (2002) investigated the influence of ownership concentration (as represented by the shares held by the ten largest shareholders) on voluntary disclosures in Malaysia and found a positive relationship. Luo, Courtenay, and Hossain (2006) provided evidence that the existence of outside block ownership considerably increases corporate voluntary disclosures by management in Singapore. Given that there are both arguments for expecting a positive and a negative relationship, no prediction of the sign of the relation is predicted. The hypothesis is therefore set out as follows:

\section{$H_{3}:$ There is a significant relationship between ownership concentration and GHG} information disclosure.

\section{Director share ownership}

Managerial participation in ownership is considered one way of overcoming agency problem as it helps to align managerial interests to those of owners (Jensen and Meckling, 
1976). Management exerts strong influence on the type of information communicated to outsiders because they are fully aware that outsiders judge their performance based on the disclosed information. Managerial share ownership places the burden of economic consequences arising from managerial actions on management themselves, thereby mitigating agency costs; hence management have incentives to reduce the cost of making more disclosures (Jensen and Meckling, 1976). In this case therefore firms with low managerial ownership could be said to have more agency costs and the need for more disclosures as a way of mitigating the costs. In addition, Morck, Shleifer and Vishny (1988) argued that managerial ownership presents an opportunity for managers to pursue self-interest non-value maximising actions at the expense of their shareholder wealth. These non-value maximising actions may include withholding of information or making inappropriate disclosures. There is evidence that increased insider or managerial ownership could lead management to make aberrant decisions (Dunn, 2004). Ghazali (2007) argued that substantial investment expected or required to be made in systems to enable a firm to discharge social and environmental responsibilities, coupled with uncertainty as to the payback possibility of such investment, may make managers with high share ownership resist voluntary activities including disclosures. The studies of Ghazali and Weetman (2006) and Haji (2013) found managerial ownership to be negatively associated with disclosure. On the contrary, Johnson and Greening (1999) argued that increased managerial ownership increases the probability of managers being sympathetic to social and environmental activities as they deem them potentially able to create goodwill, thus inducing customers to be more favourably disposed to their companies' products, which will in turn improve the companies' standings with other stakeholders like bankers, government and investors. However their results found that though managerial ownership was positively related to multi-stakeholder needs, their relationship with the people dimension of corporate social performance was insignificant, leading them to 
conclude that 'top managers' equity does not contribute to a managerial emphasis on communities, women, minorities, and employees' (Johnson and Greening, 1999:574). Therefore in this study managerial ownership (represented by proportion of ordinary share ownership by executive and non-executive directors) is expected to be related to GHG disclosures in the negative form; hence the hypothesis is set out as follows:

$H_{4}$ : There is a negative relationship between directors' share ownership and GHG information disclosure

\section{Control Variables}

Based on prior literature (Freedman and Jaggi, 2005; Prado-Lorenzo, RodriguezDominquez, Gallego-Alvarez, and Garcia-Sanchez, 2009; Rankin et al., 2011; Berthelot and Robert, 2011; Stany and Ely, 2008; Peters and Romi, 2012; Brammer and Pavelin, 2008) we control for firm size. Size is regarded as a proxy for organisational visibility which exposes a firm to intense public scrutiny resulting in greater responsiveness towards environmental and GHG issues (Henriques and Sadorsky, 1999). We also control for financial performance. Prior literature evidence on the relationship between financial performance and GHG disclosure is, however, mixed. Some studies have found a positive relationship between GHG disclosures and financial performance (Berthelot and Robert, 2011; Liu and Anbomuzhi, 2009); but the majority of GHG disclosure have found no significant relationship (PradoLorenzo et al., 2009; Rankin et al., 2011; Peters and Romi, 2012). Our other control variable is leverage which Tang and Luo (2011) found to be positively associated with GHG disclosures. However, Prado-Lorenzo et al. (2009); Rankin et al. (2011); Freedman and Jaggi (2005) and Cotter and Najer (2011) found it to be insignificant. Unlike other prior studies we include the liquidity variable in our model on the basis that highly liquid companies are 
expected to have adequate ready resources to enable them to manage climate change challenges.

\section{Research methodology}

\subsection{Modelling and data}

To address our research objective, a mixed-method approach using both quantitative and qualitative methods was employed. Teddlie and Tashakkori (2003) suggest that mixed methods are superior to single approach designs in three ways. First, they can answer research questions that the other methodologies cannot. Second, mixed methods research provides better (stronger) inferences and finally, mixed methods provide the opportunity for presenting a greater diversity of divergent views. Brannen (2005, p. 12) identifies four functions, besides corroboration, of mixed methods research. These include: elaboration or expansion - 'the use of one type of data analysis adds to the understanding being gained by another'; initiation - 'the use of a first method sparks new hypotheses or research questions that can be pursued using a different method'; complementarity -'together the data analyses from the two methods are juxtaposed and generate complementary insights that together create a bigger picture'; and contradictions - 'simply juxtapose the contradictions for others to explore in further research'.

The study population (for both the qualitative and quantitative approaches) is the largest 1000 firms listed on the London Stock Exchange as at $30^{\text {th }}$ September, 2011. This list of firms was targeted because it covered a broad range of industries, and the size of the firms meant they were likely to adopt best reporting practices due to market pressures. This is consistent with Freedman and Jaggi (2005), Brammer and Pavelin (2006) and Prado-Lorenzo et al. (2009) who argued that large companies are likely to be required to report to regulatory agencies and to be more concerned with pollution disclosure. To arrive at our sample, 343 
financial-sector firms (including banks, insurance companies, investment trusts, unit trusts, stockbrokers and real-estate companies) were excluded because they are subject to different disclosure and statutory requirements for example, Mangena and Tauringana, 2007). Of the remaining 657 companies, 247 were excluded on the basis that they either were undergoing significant restructuring or had no corporate office in the UK. This meant that our sample consisted of 410 firms.

\subsection{Qualitative approach}

Under the qualitative approach, the study surveyed the remaining 410 firms (see above) through a questionnaire to determine whether corporate governance mechanisms are perceived as influencing GHG disclosure decisions. The survey questionnaire was based on an extensive review of literature on voluntary disclosure (Freedman and Jaggi, 2005; PradoLorenzo et al., 2009; Rankin et al., 2011; Peters and Romi, 2012; Stanny and Ely, 2008; Carter, 2006; Greenley and Foxall, 1997; Brammer and Millington, 2004; Huang and Kung, 2010; Cormier et al., 2004). The questionnaire largely used closed questions anchored on a five-point Likert scale, and was administered in August/September 2012 (see Appendix I).

In developing the questionnaire, a number of steps were taken to optimise the response rate. Thus as part of survey development and question suitability assessment, a number of university academics and researchers knowledgeable in sustainability/climate change disclosure/ and survey development were involved in preliminary stages. Five experienced academics not part of the project were invited to comment on different parts of the questionnaire such as layout, style, wording and subject content. At a minimum, we ensured that the questionnaire had appropriate introduction, instructions, and a well-arrayed set of questions with well laid down response alternatives. The understandability of the questions was rigorously tested in a pilot study. 
The questionnaire was addressed to the finance directors and stamped-addressed envelopes were enclosed for their replies. Non-respondents were followed up three times, through email, telephone and a second letter containing a copy of the questionnaire. This resulted in 86 firms responding; 62 responses were usable (i.e., all questions were completed), representing a 15.1 per cent response rate, which compared favourably with previous studies. For example, Beattie and Smith (2012) reported a response rate of 9.3 per cent, while Verma and Dewe (2004) had a 5.8 per cent response rate. Though our response rate compares favourably to prior studies, we reckon that it is still a low response rate. Baruch (1999) argued that in itself a response rate is meaningless rather the necessity and difficulty lies in explaining the low response rates. In this study, the low response rate could be attributed to a number of reasons. Our target group, the listed companies' directors are among the difficult group to target in a survey questionnaire due to their busy schedules. Ten of the companies that declined to take part sent emails through their directors' personal assistants stating that their finance directors were too busy to participate in our survey.

Beattie and Smith (2012) noted that due to the nature of this group, a response rate of between 10 and 20 per cent is considered appropriate or sufficient. The other reason could be the subject matter which is considered topical and sensitive. While non-response rates might be peculiar to certain firm characteristics i.e. size and industry, Verma and Dewe (2004) argue that it may also mean that those who did not respond did not value the subject matter and that in itself is a finding. Therefore, in our case, we consider the low response rate to be a reflection of the sensitivity surrounding climate change.

The responding firms and a sample of those that did not respond were subjected to non-response bias tests to determine the representativeness of respondents. In particular, a two-tailed $t$-test was performed using the mean turnover and number of employees of the initial sample and the responding firms; the outcome was not statistically significant. In line 
with prior studies (Darnall, Henriques and Sadorsky, 2010), we also ensured that our survey was free from a social-desirability bias. This was achieved by ensuring that all respondents were informed of their anonymity and was unaware that their responses would be compared with actual disclosure in annual and sustainability reports. One characteristic of socialdesirability bias is that there is less variability in responses, which could affect the statistical significance of the results.

The analysis was in large part based on descriptive statistics. In addition, apart from ranking based on mean, based on prior literature (Graham, Harvey and Rajgopal, 2005; Naumanand Giel, 1995), a modified top two box and bottom two box scores were used to explore the pattern of the responses. Using this approach, the original five point scale in the surveys was collapsed to increase the clarity of the data for reporting purposes. Scales were collapsed into "bottom two box" and "top two box" scores. Bottom two box scores represented the percentage of respondents who selected responses that were considered negative i.e. disagree or strongly disagree, taken from the bottom portion of the five point scale. The top two scores represent the percentage of respondents who selected responses that were considered positive i.e. agree or strongly agree. The middle column which referred to neutrality formed its own group. Thereafter the summarized results were subjected to a $t$ test between the mean score of each item and its neutral score.

\subsection{Quantitative approach}

With the quantitative approach the study employed the research index methodology to quantify GHG disclosure in the annual reports, sustainability reports and websites of the 62 firms with usable responses. The first step in quantifying GHG voluntary disclosures was to draw up a GHG disclosure list of items based on prior literature. Unlike previous studies (e.g. Prado-Lorenzo et al., 2009) which based their list of items on one GHG disclosure guidance, we included all relevant items from several GHG reporting frameworks such as Greenhouse 
Gas Protocol (2004), Global Reporting Initiative (2006), DEFRA (2009), British Standard ISO 14064-1 (2006), Global Framework for Climate Risk Disclosure (2006) and Climate Disclosure Standard Board ( 2012). The final index had 60 items consisting of 34 items relating to qualitative disclosures and 26 quantitative disclosures (see Appendix II). This checklist is comparatively broader and comprehensive than previous studies such as PradoLorenzo et al. (2009) who had a checklist of nineteen items only; Choi, Lee, and Psaros (2013) had eighteen items based on CDP questionnaire, and Freedman and Jaggi (2005) had only five items relating to GHG and global warming. The validity and suitability of the research index was reviewed and confirmed by two independent academics experienced in disclosure index based studies.

To quantify the GHG disclosures content analysis technique was used. This has been widely used in disclosure studies (Hossain, Tan, and Adams, 1994; Mangena and Tauringana, 2007; Prado-Lorenzo et al., 2009). Literature has suggested that the quantification of disclosure can either be done on a weighted or unweighted basis. Gray, Kouhy, and Lavers, (1995) suggested that the adoption of either method does not materially alter the results. An unweighted approach was adopted for this study which is most appropriate when no importance is given to any specific user groups (Cooke, 1989; Hossain et al., 1994). A company was awarded a score of ' 1 ' for the disclosed item, and ' 0 ' if not disclosed. However, the company was not penalised if the item did not apply. The total disclosure index score was then captured for each sample firm as a ratio of the total disclosure score divided by the maximum possible disclosure for the company. The disclosure index for each company was then expressed as a percentage. We then used the Ordinary Least Squares (OLS) regression to model the relationship between corporate governance variables, firms specific control variables and GHGs disclosure. The estimated model was as follows: 

GHG DIS $_{\mathrm{x}}=\beta_{0}+\beta_{1}$ Boardsize $_{\mathrm{x}}+\beta_{2}$ Non-executive $_{\mathrm{x}}+\beta_{3}$ Owncon $_{\mathrm{x}}+\beta_{4}$ Down $_{\mathrm{x}}+\beta_{5}$ Size $_{\mathrm{x}}+$ $\beta_{6}$ Profitability $_{\mathrm{x}}+\beta_{7}$ Leverage $_{\mathrm{x}} \beta_{8}$ Liquidity $_{\mathrm{x}}+\varepsilon$
Where;

GHG DIS $_{\mathrm{x}}$ is the Greenhouse Gas emissions disclosure index obtained after analysing company x's annual report;

Boardsize $_{\mathrm{x}}$ is the number of people making up the board committee of company $\mathrm{x}$.

Non-executive $_{\mathrm{x}} \quad$ is company $\mathrm{x}$ 's ratio of non-executive directors on the board;

Owncon $_{\mathrm{x}} \quad$ is propotion of shareholding by shareholders with three per cent or more;

$\operatorname{Down}_{\mathrm{x}} \quad$ is proportion of shares held by directors of the company;

Size $_{\mathrm{x}} \quad$ is company x's variable related to corporate size (total assets);

Profitability $_{\mathrm{x}}$ is company $\mathrm{x}$ 's variable representing profitability e.g. profit after tax;

Gearing $_{\mathrm{x}}$ is company $\mathrm{x}$ 's gearing, established as the ratio between total debt and stockholders' equity;

Liquidity $_{\mathrm{x}} \quad$ is company $\mathrm{x}$ 's liquidity (current assets/current liabilities)

$\mathrm{B}_{1-8} \quad$ Coefficients

$\varepsilon \quad$ Residual

$\beta_{0} \quad$ Constant

Though our aim was to triangulate results from secondary data with those obtained from primary data, our final model excluded two variables, namely CEO duality and board environmental committee, which were included in the survey questionnaire. Based on our sample (final sample determined by total respondents i.e. 62), these were deemed inadequate to generate meaningful statistical results since there were only three firms with CEO duality while only nine firms had a social and environmental committee. 


\section{Results and discussion}

\subsection{Respondents' background and descriptive statistics \\ 4.1.1 Respondents' background}

The results of Section A of the questionnaire (see Appendix I) indicated that out of the 62 respondents, seventeen or 27 per cent identified themselves as having a senior position in finance and accounting, nine or 14.5 per cent stated that they were company secretaries and/or investor relations directors while the majority, 36 or 58 per cent indicated they were senior managers or heads of sustainability and environment. The fact that the majority were senior managers dealing with environmental issues is not a cause for concern as such individuals are considered appropriate replacements of finance directors when it comes to disclosures of environmental information (Wilmhurst and Frost, 2000). For example, Cormier et al. (2004) suggested that environmental managers should be the focus of attention with respect to environmental disclosures since they are managers who implement the broad disclosure policies established by the board and communicated by the CEO. Regarding gender, only seventeen per cent of respondents were female, an indication of male dominance in senior management positions within the sample.

The majority of the respondents (33 i.e. 53 per cent) indicated they were below fifty years of age while 47 per cent were fifty or older. Twenty three (23) of the respondents or 37 per cent indicated that they had been in their positions for a period of over ten years while 63 per cent had been in their positions for a period of between four and nine years. Solomon and Lewis (2002) noted that length of service was important because the longer someone stays in a position the more knowledgeable they are. In levels of education, 48.3 per cent stated that they had qualifications above a college degree, while the rest indicated that they were in possession of a college degree. 


\subsubsection{Descriptive statistics}

Table 1 presents the descriptive statistics of the GHG information disclosure, corporate governance mechanisms and control variables. On average, companies disclosed about 31 per cent of the items on the index and the minimum and maximum being five per cent and 88 per cent respectively. This clearly demonstrates the variation existing among UK companies in their voluntary decisions of GHG information. Block holders own on average, 41.1 per cent of the firms' shares. The mean directors' share ownership was 5.99 per cent of the shares and the board of directors' was eight per cent. Our sample had firms ranging from $£ 35.26$ million to $£ 61382$ million in size (measured by total assets) and the mean was $£ 4046.24$ million. The average ROA is 9.36 per cent but the minimum stretched to minus 16.13 per cent.

\section{[Table 1 about here]}

\subsection{Correlation analysis}

Table 1 also show the correlation between all variables used in the study. As expected, GHG disclosure is positively related with size, board size, NED and liquidity. Gearing, director ownership, ownership concentration and profitability are negatively correlated with GHG disclosures but it is only ownership concentration whose relationship is significant. There were also some significant correlations between independent variables with the highest being that of firm size and board size at 0.56 . However this is considered no threat as it falls below the maximum threshold of 0.8 or 0.9 as recommended by Field (2009). Although our correlation matrix does not depict a highly significant correlation between the independent variables, we also analysed the variance inflation factors. According to Field 
(2009), low values of VIF are expected if the multi-collinearity problem is to be controlled. Our mean VIF was 2.53 and the highest VIF was five for director ownership. This means then that multi-collinearity is not prevalent in our model. To control for hetero-scedasticity in the standard errors we used the option of robust in Stata (Greene, 2008). Thus apart from just addressing hetero-scedasticity issues, the robust option deals with other minor concerns bordering on failure to meet other assumptions like normality or excessively large residuals, or influence from a particular variable. Therefore without altering the point estimates of the coefficient as derived from OLS, with the robust option, standard errors adjust for nay concerns of data abnormality or hetero-scedasticity.

\subsection{Qualitative results}

Respondents were asked to consider a list of ten variables (six corporate governance mechanisms and four firm specific variables) and then to indicate on a five point Likert scale (1-strongly disagree to 5-strongly agree) the extent to which each of the variables influence GHGs voluntary disclosure in their firms (see Appendix I, Section B). Results are presented in Table 2. The results of a two way sample $t$-test for the four corporate governance mechanisms (board size, proportion of non-executive directors, ownership concentration and directors' share ownership) that were also investigated using the quantitative approach (see 4.4 below) indicated that all the mean scores were statistically different from the neutral point $(3=$ neutral $)$ and significant at a one per cent level, except that for institutional ownership. Since the mean values of the three other corporate governance mechanisms (board size, proportion of non-executive directors and directors' share ownership) are all below the neutral point, this suggests that the respondents do not agree that GHG voluntary disclosures are influenced by three corporate governance mechanisms. Similarly, the lack of significant 
difference in respect of institutional ownership means that there is no evidence to suggest that the respondents perceive institutional ownership as influencing GHG voluntary disclosures.

\section{[Table 2 about here]}

Of the remaining corporate governance mechanisms (CEO duality and sub-board committee on environment) included in the questionnaire but not in the regression analysis below, the results suggest that their $t$-values are both statistically significant from the mean. However, the mean value of 3.40 in respect of the sub-board committee on the environment which is above the neutral point of 3.0 means that this mechanism is perceived as having a significant influence on GHG voluntary disclosure. The mean value for CEO duality of 2.33 which is below the neutral point suggests that this mechanism does not significantly influence the extent of GHG voluntary disclosures. Finally, the results in Table 2 also show the results in respect of firm specific variables (size, gearing, profitability and liquidity). The results show that the mean values of the four firm specific variables are all different form the neutral point and statistically significant at a one per cent level except profitability. However, the fact that the mean value for firm size is higher than the neutral point means that this variable is perceived as having a significant influence by our respondents. In fact about 55 per cent of survey respondents either agreed or strongly agreed that size plays a vital part in GHG disclosure decisions. Since the mean values relating to gearing, profitability and liquidity are all below $(3=$ neutral), these suggest that these three variables do not influence GHG disclosure decisions.

\subsection{Regression results}


Table 3 shows the results of our regression model including the four corporate governance (board size, proportion of non-executive directors, ownership concentration and directors' share ownership) and firm specific control variables (size, profitability, gearing and liquidity). The $R^{2}$ adjusted is 29.2 per cent and the model is highly significant $(F=3.84$, $p=0.000$ ). Our results indicate that two corporate governance mechanisms, board size and proportion of non-executive directors' are not significantly associated with GHG disclosure means that hypotheses $\mathrm{H}_{1}$ and $\mathrm{H}_{2}$ are rejected. However, the results also indicate that the other two corporate governance mechanisms (ownership concentration and director ownership) have a significant negative relationship with GHG information disclosure. This suggests that our hypotheses $\mathrm{H}_{3}$ and $\mathrm{H}_{4}$ in respect of ownership concentration and directors' share ownership are confirmed $(\beta=-.02, \mathrm{p} .01 ; \beta=-.01, \mathrm{p} .001)$ respectively. Of the control factors, only size and liquidity are significant $(\beta=.07, \mathrm{p} .001 ; \beta=.02, \mathrm{p} .01)$ while profitability and gearing are not.

\section{[Table 3 about here]}

\subsection{Discussion}

The results from the two research methods (qualitative and quantitative) are consistent in that they both suggest that corporate governance characteristics (board size and proportion of non-executive directors) do not determine the extent of GHG disclosures. The lack of support for the relationship between these governance variables and GHG disclosure, while surprising, is in line with a growing body of literature that suggest the inadequacy of existing board structures in championing sustainability reporting (Michelon and Parbonetti 2012; Walls, Berrone, and Phan, 2013). Wang and Hussainney (2013) argued that it is still debatable as to whether certain governance characteristics as advocated by UK corporate governance guidance are effective in improving narrative reporting in general. Mallin, 
Michelon and Raggi, (2013) suggested that there is no straightforward relationship between corporate governance and social and environmental disclosures, and hence called for innovative techniques to prove the link.

The results from both the qualitative and quantitative approach may also suggest that traditional board proxies are not effective/good enough to depict the role of the board relating to legitimating activities. This could explain why when put to them, survey respondents unequivocally disagreed with a score of over 50 per cent on each item i.e. board size, NED, and CEO duality, that these do influence disclosure decision, but unanimously agreed with presence of a board sub-committee on environment. Being a new phenomenon (only nine firms in our sample had such a committee), the strong agreement by survey respondents may suggest that firms now realise the need to go beyond existing board structures in order to discharge their environmental information disclosure responsibilities. Kolk, Levy, and Pinkse (2008) alluded to the fact that board characteristics such as board size and NEDS were primarily designed for different set of objectives, and so may not be useful in achieving environmental information disclosure objectives. Moreover researchers have found evidence that despite all the talk about environment and governance, the directors perceive their role as being primarily centred on the old tradition of protecting shareholders' interests, and hence they set aside any stakeholder pressure for more environmental action as their reputation is not at stake (Rodrigue et al., 2013; Hillman, Keim and Luce, 2001).

On the other hand, our two research approaches yielded different results for the other two corporate governance variables (ownership concentration and directors' share ownership). While we found a negative and significant influence of both ownership structures through secondary data, we documented strong rejection by the survey respondents relating to GHG disclosure decisions. This could be interpreted from two perspectives. The strong disagreement from respondents could arguably imply that due to the current form of 
corporation in which ownership is diversified from management and to the increased emphasis on the board of directors rather than on shareholders, managers perceive shareholders as being of no significant influence in implementing policy including disclosure.

Alternatively the explanation could lie in how far 'shareholder activism' (Reid and Toffel, 2009) influences managerial decision making. First, it is understood that, on its own, shareholder activism has little chance of success in influencing managerial decisions on social and environmental issues unless it is channelled through other means such as advocacy groups (Gillan and Starks, 2007; Reid and Toffel, 2009). This could be true for climate change and GHG emissions disclosures where managers may perceive compliance with requirements set by private groups like the Carbon Disclosure Project (CDP) requirements (an NGO grouping of investors promoting transparency and accountability on GHGs) as being more important than responding to their own shareholder demands. Consistent with the prediction of stakeholder theory, shareholder activism gains salience, power and legitimacy through groupings such as CDP or CERES which then forces managers to respond rather than just responding to their own shareholder demands (Cotter and Najar, 2011). According to Mitchel, Agle and Wood (1997) stakeholder demands are met in accordance with power and legitimacy hierarchy. Second, there is mounting evidence that in most cases formal shareholder pressure on management through resolutions is often rejected by management due to either management refusing to be seen to cede decision-making power or simply dismissing the resolutions as being too far from reality (Hoffman, 1996; Sasser, Prakash, Cashore and Auld, 2006). Therefore since our survey respondents were people of senior standing within the firms, we argue that their rejection of external influence in the form of ownership could be a manifestation of this desire to demonstrate that they maintain discretion over matters of strategic and operational importance. 
We found agreement between both secondary and survey results relating to the influence of size, gearing and profitability but contradictory results were reported for liquidity. The unanimous agreement on size demonstrates that more than anything managers understand that size moderates the extent of their discretion in responding to multistakeholder demands for GHG information. As argued by Darnall et al. (2010) size also determines how other stakeholders view or react to managerial action on issues at hand. The evidence from both data sources that gearing and profitability plays no part in GHG disclosures follows a consistent pattern of evidence from prior studies that when taken together questions the validity of these financial variables in environmental or GHG studies. Guidry and Patten (2012) wondered why voluntary disclosure based theories based models particularly from financial disclosure literature have been used in environmental disclosure studies without careful consideration. Their study which reviewed a number of environmental disclosure studies failed to find evidence supporting that financial control variables such as profitability and gearing were relevant in environmental disclosure research. The contradiction on liquidity was not unexpected but is difficult to put it in perspective since many research results using secondary data excluded it from their models, making comparison difficult. Lack of survey based results notwithstanding, we are inclined to argue that liquidity could be seen in the light of resource availability just as much as size, hence its positive impact from secondary data. This could be corroborated by what some survey respondents stated in their additional comments. For instance, some respondents (five) stated that more than anything it is the cost of setting up viable systems for GHG measurement and control that influences extent of disclosure and this may indirectly relate to liquidity issues.

\section{Summary and Conclusion}


In the wake of conflicting results as to the efficacy of corporate governance mechanisms in determining the extent of disclosure, this study responded to the calls by Adams (2002) and Beattie and Smith (2012) among others, for qualitative research of the determinants of disclosure. Specifically, the study investigated whether corporate governance mechanisms (board size, proportion of non-executive directors, ownership concentration and directors' share ownership) determine the extent of GHG disclosure while controlling for firm specific characteristic (size, profitability, gearing and liquidity). Since, it was the first time that the qualitative approach has been used to investigate whether corporate governance determine the extent of GHG disclosures, we also used the quantitative approach in order to compare the results of our qualitative approach.

Overall, the results indicate that there are some similarities and also some differences in the results of the qualitative and quantitative approaches. In terms of similarities, both approaches suggest that firm corporate governance mechanisms (board size and NEDs) and firm specific control variables (profitability and leverage) do not have a significant impact on GHG disclosures. The results of the two approaches are also similar in that they both suggest that firm size determine the extent of GHG disclosure. In terms of differences, the qualitative approach, the results suggest corporate governance mechanisms (ownership concentration and directors' share ownership) and firm specific characteristic (liquidity) do not influence the extent of GHG disclosure while the quantitative approach suggest that they have significant influence.

The consistent finding by both research approaches that both board size and proportion of non-executive directors do not determine the extent of GHG disclosure adds to growing empirical evidence that question the adequacy of existing board structures in serving wider needs including climate change. Consistent with this view, Wang and Hussainney (2013) argued that it is still debatable as to whether certain governance characteristics as 
advocated by UK corporate governance guidance are effective in improving narrative reporting in general. The results are of particular importance to some key stakeholders notably the Corporate Governance or Regulatory authorities and investors who leans towards environmentally responsible investments. As governance codes are periodically reviewed then the results may help the authorities to recommend board structures that will help firms overcome the GHG disclosure challenges. For environmentally conscious investors, the governance characteristics found to influence GHG disclosure may form a starting point of consideration when planning their investments.

There are a number of limitations with our study. One limitation of our study was the use of cross-sectional data, which meant we could not identify the dynamic effects among our determinants of GHG disclosure. While this was necessary due to the need to triangulate with the primary data, future research needs to track the pattern of disclosure over a period of time. Future work that also focuses on in-depth interviews might also bring useful insights as to whether corporate governance mechanisms have any role to play in GHG disclosure. It is also possible that the findings of this study might be limited to the UK. Future studies should, therefore, investigate whether practitioners in other countries view these corporate governance mechanisms as influencing their GHG disclosure decisions. Another limitation is the response rate which though at 15.1 per cent is considered adequate, constrain the extent to which we can generalise the findings. Some may also point to the vulnerability of using a survey in establishing whether corporate governance mechanisms determine GHG disclosures from practitioners because of its proneness to response bias. However, our use of secondary data sources to compare and contrast the managerial perceptions, and of statistical tests (which failed to provide evidence of such bias), might counter that argument. In spite of these limitations, our study contributes both to the academic debate regarding the efficacy of corporate governance mechanisms in determining disclosures in general and GHG 
specifically. In particular, study fills the void for qualitative based study on the determinants of disclosure which academic researchers (for example, Adams 2002; Michelon and Parbonetti, 2012) having been calling for to be filled. In addition, our mixed method research design also enabled us to triangulate by presenting qualitative and quantitative results of the determinants of GHG disclosure side by side. Such evidence to the best of our knowledge does not currently exist.

\section{References}

Adams, C.A. (2002), "Internal organizational factors influencing corporate social and ethical reporting: Beyond current theorizing", Accounting, Auditing and Accountability Journal, Vol.15 No. 2, pp. 223-250.

Akhtaruddin, M., Hossain, M.A., Hossain, M and Yao, L. (2009), "Corporate governance and voluntary disclosure in corporate annual reports of Malaysian listed firms", Journal of Applied Management Accounting Research, Vol.7 No.1, pp. 1-19.

Baruch, Y. (1999), "Response rates in academic studies - a comparative analysis", Human Relations, Vol. 52 Iss: 4, pp. 421-34.

Beattie, V. and Smith, J. (2012), "Evaluating disclosure theory using the views of UK finance directors in the intellectual capital context", Accounting and Business Research, Vol. 42 No. 5, pp. 1-24.

Beasley, M.S., Carcello, J.V., Hermanson, D.R. and Lapides, P. D. (2000), "Fraudulent financial reporting: Consideration of industry traits and corporate governance mechanisms", Accounting Horizons, Vol. 14 No. 4, pp. 441-454.

Berthelot, S. and Robert, A.M. (2011), "Climate change disclosures: An examination of Canadian oil and gas firms", Issues in Social and Environmental Accounting, Vol. 5 No. 2, pp. 106-123.

Brammer, S. and Millington, A. (2004), "The development of corporate charitable contribution in the UK: A stakeholder analysis", Journal of Management Studies, Vol. 41, No. 8, pp. 1412-1434.

Brammer, S. and Pavelin, S. (2006), "Voluntary Environmental Disclosures by Large UK Companies", Journal of Business Finance and Accounting, Vol. 33 No. 7/8, pp. $1168-$

1188. 
Brammer, S. and Pavelin, S. (2008), "Factors Influencing the Quality of Corporate Environmental Disclosure", Business Strategy and the Environment, Vol. 17 No. 2,

pp. $120-136$.

Brannen, J. (2005), "Mixed methods research: a discussion paper", NCRM methods review papers, ESRC National Centre for Research Methods, Southampton.

British Standard ISO 14064-1: (2006) - Greenhouse gases - Part 1: Specification at the organization level for the quantification and reporting of greenhouse gas emissions

and removals, BS0, London.

Carter, S. (2006), "The interaction of top management group, stakeholder and situational factors on certain corporate reputation management activities", Journal of Management Studies, Vol. 43 No.5, pp. 1145-1176.

Chen, C.J.P. and Jaggi, B. (2000), "Association between independent non-executive directors, family control and financial disclosures in Hong Kong", Journal of Accounting and Public Policy, Vol. 19 No. 4/5, pp. 285-310.

Choi, B.B., Lee, D., and Psaros, J. (2013), "An analysis of Australian company carbon emission disclosures", Pacific Accounting Review, Vol. 25 No. 1, pp. 58-79.

The Climate Disclosure Standards Board (2012) Climate Change Reporting Framework, available at: http://www.cdsb.net/sites/cdsbnet/files/cdsb_climate change_reporting_framework_edition_1.1.pdf

Collier, P. and Zaman, M. (2005), "Convergence in European corporate governance: the audit committee concept", Corporate Governance: An International Review, Vol. 13 No. 6, pp. 753-68.

Cooke, T.E. (1989), "Disclosure in the corporate annual report of Swedish Companies", Accounting and Business Research, Vol. 19 No.74, pp. 113-124

Cormier, D., Ledoux, M., Magnan, M. and Aerts, W. (2010), "Corporate governance and information asymmetry between managers and investors", Corporate Governance: The International Journal of Business in Society, Vol.10 No. 5, pp. 574-589.

Cormier, D., Gordon, I.M. and Magnan, M. (2004), "Corporate environmental disclosure: Contrasting management's perceptions and reality", Journal of Business Ethics, Vol. 49 No. 2, pp. 143-165.

Cotter, J. and Najah, M. (2011), "Institutional investor influence on global climate change disclosure practices", Australian Journal of Management, Vol. 37 No. 2, pp. 169-18.

Darnall, N., Henriques, I. and Sadorsky, P. (2010), "Adopting proactive environmental strategy: The influence of stakeholders and firm size", Journal of Management Studies, Vol. 47 No. 6, pp. 1072-1094.

DEFRA. (2009). Guidance on how to measure and report your greenhouse gas emissions. available at www.defra.gov.uk/environment/business/.../ghg-freight-guide.pdf.

Dixon, R., Milton, K. and Woodhead, A. (2005), "An Investigation into the role, effectiveness and future of non-executive directors", Journal of General Management, Vol. 31 No.1, pp. 1-21.

Donnelly, R. and Mulcahy, M. (2008), "Board structure, ownership, and voluntary disclosure in Ireland", Corporate Governance: An International Review, Vol. 16 No. 5, pp. 416429.

Dunn, P. (2004), "The impact of insider power on fraudulent financial reporting", Journal of Management, Vol. 30 No. 3, pp. 397-412.

Fama, E.F. and Jensen, M.C. (1983), "Agency problems and residual claims", Journal of Law and Economics, Vol. 26 June, pp. 301-325.

Field, A. (2009). Discovering statistics using SPSS. $3^{\text {rd }}$ Edition. Sage publishers, London 
Forker, J. R. (1992), “Corporate governance and disclosure quality”, Accounting and Business Research, Vol. 22 No. 86, pp. 111-124.

Freedman, M. and Jaggi, B. (2005), "Global warming, commitment to the Kyoto Protocol, and accounting disclosures by the largest global public firms from polluting industries", The International Journal of Accounting, Vol. 40 No. 3, pp. 215-32.

Galbreath, J. (2010), "Corporate governance practices that address climate change: an exploratory study”, Business Strategy and the Environment, Vol. 19 No. 5, pp. 335-

350 .

Ghazali, N.A.M. (2007), "Ownership structure and corporate social responsibility disclosure: some Malaysian evidence”, Corporate Governance, Vol. 7 No. 3, pp. 251-266.

Ghazali, N.A. and Weetman, P. (2006), "Perpetuating traditional influences: voluntary disclosure in Malaysia following the economic crisis", Journal of International Accounting, Auditing and Taxation, Vol. 15 No. 2, pp. 226-248.

Gillan S.L, Starks L.T. (2007), "The evolution of shareholder activism in the United States", Journal of Applied Corporate Finance, Vol. 19, pp. 55-73.

Global Framework for Climate Risk Disclosure (2006) available at: http://www.unepfi.org/fileadmin/documents/global_framework.pdf, (accessed 24.5.2014).

Global Reporting Initiative (2006), "Sustainability reporting guidelines", available at: www.globalreporting.org/resourcelibrary/G3-Sustainability-Reporting Guidelines.pdf (accessed 10 December 2014)

Graham, J.R., Harvey, C. R. and Rajgopal, S. (2005), "The Economic implications of corporate financial reporting", Journal of Accounting and Economics, Vol. 40 No. 1-

3 ,

pp. 3-73.

Gray, R., Kouhy, R. and Lavers, S. (1995), "Corporate social and environmental reporting. A review of the literature and a longitudinal study of UK disclosure", Accounting, Auditing and Accountability Journal, Vol. 8 No.2, pp. 47-77.

Gray, R., Javad, M., Power, D.M. and Sinclair, C.D. (2001), "Social and environmental disclosure and corporate characteristics: A research note and extension", Journal of Business Finance and Accounting, Vol. 28 No. 3-4, pp. 327-56.

Greene WH. (2008), Econometric Analysis. Pearson: NJ.

Greenhouse Gas Protocol (2004), "A corporate accounting and reporting standard", available at: www.ghgprotocol.org/files/ghgp/public/ghg-protocol-revised.pdf (accessed October 2015).

Greenley, G. and Foxall, G. (1997), "Multiple stakeholder orientation in UK companies and the implications for company performance", Journal of Management Studies, Vol. 34 No. 2, pp. 259-284.

Guidry, R. and Patten, D. (2012), "Voluntary disclosure theory and financial control variables: An assessment of recent environmental disclosure research", Accounting Forum, Vol. 36 No. 2, pp. 81-90.

Haji, A.A. (2013), "Corporate social responsibility disclosures over time: evidence from Malaysia”, Managerial Auditing Journal, Vol. 28 No. 7, pp. 647-676.

Haniffa, R. M. and Cooke, T. E. (2002), "Culture, corporate governance and disclosure in Malaysian corporations", Abacus, Vol. 38 No. 5, pp. 317-349.

Henriques, I. and Sadorsky, P. (1999), "The relationship between environmental commitment and managerial perceptions of stakeholder importance", Academy of Management Journal, Vol. 42 No. 1, pp. 87-99. 
Hillman, A.J., Keim, G.D. and Luce, R.A. (2001), "Board composition and stakeholder performance: Do stakeholder directors make a difference?" Business and Society, Vol. 40 No. 3, pp. 295-314.

Ho, S.S.M. and Wong, K.S. (2001), "A study of corporate disclosure practice and effectiveness in Hong Kong", Journal of International Financial Management and Accounting, Vol. 12 No. 1, pp. 75-102.

Hoffman, A.J. (1996), “A strategic response to investor activism", Sloan Management Review, Vol. 37 No. 2, pp. 51-64

Hossain, M., Tan, L. M. and Adams, M. (1994), "Voluntary disclosure in an emerging capital market: some empirical evidence from companies listed on the K.L. Stock Exchange", International Journal of Accounting, Vol. 29, pp. 334-351.

Huang, C. and Kung, F. (2010), "Drivers of environmental disclosure and stakeholder expectation: Evidence from Taiwan", Journal of Business Ethics, Vol. 96 No. 3, pp. 435-451.

Jensen, M.C. and Meckling, W.H. (1976), "Theory of a firm: managerial behaviour, agency costs and ownership structure", Journal of Financial Economics, Vol. 3 No. 4, 305360 .

Johnson, R.A. and Greening, D.W. (1999), "The effects of corporate governance and institutional ownership types on corporate social performance", Academy of Management Journal, Vol. 42, pp. 564-576.

Johnson, R.B., Onwuegbuzie, A.J. and Turner, L.A. (2007), "Toward a definition of mixed methods research", Journal of Mixed Methods Research, Vol. 1 No. 2, pp. 112-133.

Kolk, A. and Pinkse, J. (2004), "Market strategies for climate change", European Management Journal, Vol. 22 No.3, pp. 304-314.

Kolk, A., Levy, D., and Pinkse, J. (2008), "Corporate responses in an Emerging Climate Regime: The Institutionalisation and Commensuration of Carbon Disclosures", European Accounting Review, Vol. 17 No. 4, pp. 719 - 745.

Kumar, P. and Zattoni, A. (2013), "Corporate governance, board of directors, and firm performance", Corporate Governance: An International Review, Vol. 21 No. 4, pp. 311-313.

Liu, X., and Anbumozhi, V. (2009), "Determinant factors of corporate environmental information disclosure: an empirical study of Chinese listed companies", Journal of cleaner production, Vol. 17 No. 6, pp. 593-600.

Luo, S., Courtenay, S.M. and Hossain, M. (2006), "The effect of voluntary disclosure, ownership structure and proprietary cost on the return-future earnings relation", Pacific-Basin Finance Journal, Vol. 14 No. 5, pp. 501-521.

Mallin, C., Michelon, G. and Raggi, D. (2013), "Monitoring Intensity and Stakeholders' Orientation: How does Governance affect Social and Environmental Disclosure?" Journal of Business Ethics, Vol. 114 No. 1, pp. 29-43.

Matolcsy, Z., Y. Shan, Y. and Seethamraju, V. (2012), "The timing of changes in CEO compensation from cash bonus to equity-based compensation: Determinants and performance consequences", Journal of Contemporary Accounting and Economics, Vol. 18 No. 2, pp. 78-91.

Mangena, M. and Tauringana, V. (2007), “Corporate compliance with non-mandatory statements of best practice: the case of the ASB statement on interim reports", European Accounting Review, Vol. 16 No. 2, pp. 1-29.

Michelon, G. and Parbonetti, A. (2012), "The effect of corporate governance on sustainability disclosure", Journal of Management and Governance, Vol. 16 No. 3, pp. 477-509 
Mitchell, R. K., Agle, B. R. and Wood, D. J. (1997), “Toward a theory of stakeholder identification and salience: defining the principle of who and what really counts", Academy of Management Review, Vol. 22 No. 4, pp. 853-86.

Morck, R. Shleifer, Vishny, A.R. (1988), "Management ownership and market valuation: an empirical analysis", Journal of Financial Economics, Vol. 20 January-March, pp.

$293-$ 315

Monks R.A.G. and Minow N. (2004). Corporate Governance, 3rd edn. Blackwell: Oxford.

Nauman E and Giel K. (1995). Customer Satisfaction Measurement and Management: Using the Voice of the Customer. Cincinnati, Ohio: Thompson Publishing

Noe, T. (2002), "Institutional activism and financial market structure", Review of Financial Studies, Vol. 15 No. 1, pp. 289-319.

Peasnell, K., Pope, P.F. and Young, S. (2005), "Board monitoring and earnings management: Do outside directors influence abnormal accruals?" Journal of Business Finance and Accounting, Vol. 32 No. 7-8, pp. 1311-1346.

Peters, G.F. and Romi, A.M. (2012), The effect of corporate governance on voluntary risk disclosures: Evidence from greenhouse gas emission reporting. $h t t p: / / W w w$. Business. Utah. Edu/Sites/Default/Files/Documents/School-of-Accounting/Ghg_Disclosure_ and_Corp_Gov_20120202. Pdf.

Post, C., Rahman, N. and Rubow, E. (2011). "Green governance: Boards of directors' composition and environmental corporate social responsibility", Business and Society, Vol. 50 No. 1, pp. 189-223.

Prado-Lorenzo J.M., Rodriguez-Dominquez, L., Gallego-Alvarez, I. and Garcia-Sanchez, I.M. (2009), "Factors influencing the disclosure of greenhouse gas emissions in companies world-wide", Management Decision, Vol. 47 No.7, pp.1133 - 1157.

Prado-Lorenzo J.M. and Garcia-Sanchez, I.M. (2010), "The role of the board of directors in disseminating relevant information on greenhouse gases", Journal of business ethics, Vol. 97 No3, pp. 391-424.

Rankin, M., Windsor, C., and Wahyuni, D. (2011), “An investigation of voluntary corporate greenhouse gas emissions reporting in a market governance system Australian

$1037-$ evidence", Accounting, Auditing and Accountability Journal, Vol. 24 No. 8, pp.

1070.

Reid, E.M. and Toffel, M.W. (2009), "Responding to public and private politics: Corporate disclosure of climate change strategies", Strategic Management Journal, Vol. 30 No. 11, pp. 1157-1178.

Rodrigue, M., Magnan, M and Cho, C. H. (2013), "Is environmental governance substantive or symbolic? An empirical investigation", Journal of Business Ethics, Vol. 114 No.

1 , pp. 1331-1335.

Rupley, K.H., Brown, D. and Marshall, R.S. (2012), "Governance, media and the quality of environmental disclosure", Journal of Accounting and Public Policy, Vol. 31 No. 6, pp. 610-640.

Sasser, E.N., Prakash, A., Cashore,B., and Auld, G. (2006), "Direct targeting as an NGO political strategy: examining private authority regimes in the forestry sector", Business and Politics, Vol. 8 No. 3, pp. 1-32.

Shleifer, A. and Vishny, R. W. (1997), “A survey of corporate governance”, Journal of Finance, Vol. 52 No. 2, pp. 737-783. 
Stanny, E. and Ely, K. (2008), "Corporate Environmental Disclosures about the Effects of Climate Change", Corporate Social Responsibility and Environmental Management, Vol. 15 No. 6, pp. 338-348.

Solomon, A. and Lewis, L. (2002), "Incentives and disincentives for corporate environmental disclosure", Business Strategy and the Environment, Vol. 11 No. 3, pp. 154-69.

Tang, Q., Luo, L. (2011). Transparency of carbon disclosures: International evidence. Research paper. http://papers.ssrn.com/sol3/papers.cfm?abstract $\mathrm{id}=1885230$

Tauringana, V. and Chithambo, L. (2015), "The effect of DEFRA guidance on greenhouse gas disclosure", The British Accounting Review, Vol. 47 No. 4, pp. 425-444.

Teddlie, C. and Tashakkori, A. (2003), "Major issues and controversies in the use of mixed methods in the social and behavioral sciences", in Tashakkori, A. and Teddlie, C. (Eds), Handbook of Mixed Methods Research in Social and Behavioural Research, Sage Publications, Thousand Oaks, CA.

Financial Reporting Council (2016), The UK corporate governance code. Financial Reporting Council, London.

Verma, S. and Dewe, P. (2004), Valuing human resources. ACCA Research Report No. 83." London: Certified Accountants Educational Trust.

Walls, J.L., Berrone, P. and Phan, P.H. (2013), "Corporate governance and environmental performance: is there really a link?" Strategic Management Journal, Vol. 33 No. 8, pp. 885-913.

Wang, M. and Hussainey, K. (2013), "Voluntary forward-looking statements driven by corporate governance and their value relevance", Journal of Accounting and Public Policy, Vol. 32 No. 3, pp. 26-49.

Wilmshurst, T. D. and Frost G. R. (2000), "Corporate Environmental Reporting: A Test of Legitimacy Theory", Accounting, Auditing and Accountability Journal, Vol. 13 No. 1, pp. 10-26.

Zahra, S.A. Neubaum, D.O. and Huse, M. (2000), "Entrepreneurship in medium-size companies: exploring the effects of ownership and governance systems", Journal of Management, Vol. 26 No. 5, pp. 947-976.

\section{Table 1}

\section{Correlation and descriptive statistics}

\begin{tabular}{|c|c|c|c|c|c|c|c|c|c|c|}
\hline & & 1 & 2 & 3 & 4 & 5 & 6 & 7 & 8 & 9 \\
\hline 1 & GHG Disclosures & 1.00 & & & & & & & & \\
\hline 2 & $\begin{array}{l}\text { Board size } \\
\text { Non-Executive }\end{array}$ & $0.34 * * *$ & 1.00 & & & & & & & \\
\hline 3 & Directors & $0.21^{*}$ & 0.13 & 1.00 & & & & & & \\
\hline & Ownership & $-0.4 * * *$ & $-0.39 * *$ & -0.08 & 1.00 & & & & & \\
\hline
\end{tabular}


Concentration

\begin{tabular}{|c|c|c|c|c|c|c|c|c|c|}
\hline Director Ownership & -0.14 & 0.17 & -0.19 & $0.38 * * *$ & 1.00 & & & & \\
\hline Size & $0.38 * * *$ & $0.56 * * *$ & $0.25 * *$ & $-.39 * * *$ & -0.11 & 1.00 & & & \\
\hline Profitability & -0.15 & 0.03 & 0.09 & -0.01 & $0.24 *$ & 0.03 & 1.00 & & \\
\hline Gearing & 0.00 & 0.07 & 0.05 & 0.14 & 0.09 & 0.02 & -0.05 & 1.00 & \\
\hline Liquidity & $0.25 * *$ & -0.01 & 0.02 & 0.02 & -0.01 & $-0.43 * * *$ & $-.35 * * *$ & $-.43 * * *$ & 1.00 \\
\hline Mean & 0.31 & 8.52 & 5.99 & 41.4 & 0.04 & 4046.24 & 9.36 & 0.61 & 1.66 \\
\hline Std. Deviation & 0.23 & 2.29 & 0.14 & 20.42 & 0.12 & 9406.22 & 8.22 & 0.24 & 2.71 \\
\hline Minimum & 0.05 & 5.00 & 0.00 & 5.02 & 0.00 & 35.26 & -16.13 & 0.06 & 0.46 \\
\hline Maximum & 0.88 & 15.00 & 64.42 & 89.20 & 0.64 & 61382.00 & 32.56 & 1.32 & 21.6 \\
\hline Kurtosis & 2.86 & 3.79 & 1.89 & 2.41 & 17.16 & 27.49 & 4.49 & 3.47 & 50.8 \\
\hline $\begin{array}{l}\text { Skewness } \\
\text { Variance Inflation }\end{array}$ & 1.01 & 0.88 & 2.66 & 0.26 & 3.81 & 4.82 & 0.15 & 0.42 & 6.82 \\
\hline Factors & - & 2.20 & 1.17 & 4.69 & 5.00 & 2.45 & 1.58 & 1.46 & 1.68 \\
\hline
\end{tabular}

$N=61 * * * p<0.001, * * p<.01$

Table 2

List of GHG voluntary determinants

\begin{tabular}{lcrrrr}
\hline $\begin{array}{l}\text { Determinants of GHG } \\
\text { disclosures }\end{array}$ & $\begin{array}{l}\text { Mean } \\
\text { Score }\end{array}$ & $\begin{array}{l}\text { Standard } \\
\text { Deviation }\end{array}$ & $\begin{array}{l}\text { \% agreed or } \\
\text { strongly agreed }\end{array}$ & $\begin{array}{l}\text { \% disagree or } \\
\text { strongly } \\
\text { disagree }\end{array}$ & $\begin{array}{l}\text { \% } \\
\text { neutral }\end{array}$ \\
\hline Board committee Size & $2.10^{* * *}$ & 0.86 & $2.8 \%$ & $63.9 \%$ & $33.3 \%$ \\
& & & & & \\
$\begin{array}{l}\text { Proportion of non-executive } \\
\text { directors on the board }\end{array}$ & $2.35^{* * *}$ & 0.86 & $5.6 \%$ & $55.6 \%$ & $38.9 \%$
\end{tabular}


Presence of a sub-board committee on environment Separation of the roles of CEO and Chairman of the board Institutional Ownership i.e. majority of ordinary shares held by institutional investors Insider ownership i.e. majority of ordinary shares held by managers/employees

Size of company

$\begin{array}{rrrrr}3.40 * * & 1.23 & 62.2 \% & 21.6 \% & 16.2 \% \\ 2.33 * * * & 1.00 & 13.9 \% & 54.1 \% & 29.7 \% \\ & & & & \\ 2.73 & 1.13 & 36.1 \% & 44.4 \% & 19.4 \%\end{array}$

Company gearing i.e. capital structure

Company profitability

$2.50 * * * \quad 0.93$

$11.1 \%$

$50.0 \% \quad 38.9 \%$

Table 3

\section{Multiple regression models}

\section{Variable}

GHG disclosure (DV)

Board size

Non-Executive Directors

Ownership Concentration
Model

Std.

Coefficient Error

$\begin{array}{cc}-0.026 & 0.129 \\ -0.051 & 0.344 \\ 0.024 * * & 0.006\end{array}$




$\begin{array}{lrc}\text { Director Ownership } & -0.012 * * * & 0.004 \\ \text { Size } & 0.079 * * & 0.211 \\ \text { Profitability } & 0.003 & 0.004 \\ \text { Gearing } & 0.173 & 0.099 \\ \text { Liquidity } & 0.028^{* *} & 0.007 \\ & & \\ \text { R-squared } & 0.395 & \\ \text { Adjusted R-squared } & 0.292 & \\ * * * p<0.001, * * p<0.01, * p<0.05 & & \end{array}$

\section{Appendix I: Firm GHG disclosure and stakeholder importance}

\section{General instructions and information}

This survey questionnaire is for academic purposes only. Therefore, all responses will be held in strict confidence. No individual will be identified.

\section{Section A: Background information}


1

2

3

4

5

6

7

8

9

10

1. Please provide the following information:

\section{Information relating to yourself:}

i) Name of company

ii) Job title

iii) Gender.

Please circle the appropriate answer relating to you in each of the columns in the table below:

\begin{tabular}{|l|l|l|}
\hline iv) $\begin{array}{c}\text { Your } \\
\text { age } \\
\text { (years) }\end{array}$ & v) $\begin{array}{c}\text { Your length of } \\
\text { time in job (years) }\end{array}$ & vi) Your education \\
\hline a. $\leq 39$ & a. $<4$ & a. GCSE or equivalent \\
b. $40-49$ & b. $4-9$ & b. University degree \\
c. $50-59$ & c. $10-15$ & c. MBA \\
d. $60+$ & d. $>15$ & d. Non-MBA master's \\
& & e. >Master's \\
\hline
\end{tabular}

\section{Section B: Determinants of voluntary GHG disclosures}

1. Please indicate the extent of your disagreement or agreement with each of the following statements.

The extent of voluntary GHG disclosures is influenced by; 


\begin{tabular}{|c|c|c|c|c|c|}
\hline & 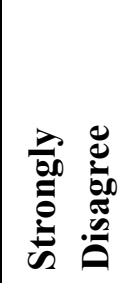 & 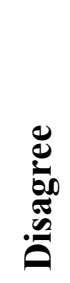 & $\underset{\bar{E}}{\bar{Z}}$ & 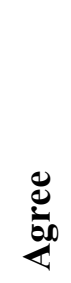 & 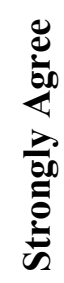 \\
\hline a. Board committee size & 1 & 2 & 3 & 4 & 5 \\
\hline $\begin{array}{l}\text { b. Presence and proportion of non- } \\
\text { executive directors on the board }\end{array}$ & 1 & 2 & 3 & 4 & 5 \\
\hline $\begin{array}{l}\text { c. presence of an sub-board committee } \\
\text { on environment }\end{array}$ & 1 & 2 & 3 & 4 & 5 \\
\hline $\begin{array}{l}\text { d. separation of the roles of CEO and } \\
\text { chairman }\end{array}$ & 1 & 2 & 3 & 4 & 5 \\
\hline $\begin{array}{l}\text { e. Institutional ownership i.e. majority } \\
\text { of ordinary shares held by } \\
\text { institutional investors }\end{array}$ & 1 & 2 & 3 & 4 & 5 \\
\hline $\begin{array}{l}\text { f. } \begin{array}{l}\text { Insider ownership i.e. } \\
\text { ordinary shajority of } \\
\text { managers/employees }\end{array} \\
\text { held by }\end{array}$ & 1 & 2 & 3 & 4 & 5 \\
\hline g. Size of your company & 1 & 2 & 3 & 4 & 5 \\
\hline $\begin{array}{l}\text { h. Company gearing } \\
\text { structure }\end{array}$ & 1 & 2 & 3 & 4 & 5 \\
\hline i. Company profitability & 1 & 2 & 3 & 4 & 5 \\
\hline j. Company liquidity & 1 & 2 & 3 & 4 & 5 \\
\hline
\end{tabular}

k. Other (please specify)

Thank you for taking the time to complete this questionnaire.

Your assistance in providing this information is very much appreciated.

If there are any comments you would like to make regarding this survey, please do so in the space provided below: 
1

2

3

4

5

6

7

8

9

10

11

12

13

14

15

16

17

18

19

20

21

22

23

24

25

26

27

28

29

30

31

32

33

34

35

36

37

38

39

40

41

42

43

44

45

46

47

48

49

50

51

52

53

54

55

56

57

58

59

60

\section{Appendix II: GHG disclosure index}

Qualitative disclosure

1 Institutional background

2 Period covered by the report 
3 Statement about company position on climate change and related responsibilities

4 Corporate governance on climate change

5 Climate-change opportunities and company strategies

6 Climate-change impact on business operations, including supply chains

7 Identification of regulatory risks as a result of climate change

8 Identification of all other risks as a result of climate change

9 Actions/measures taken to reduce/mitigate climate-change impact

10 Adaptation strategies to climate-change effects

11 Regulated schemes to which the firm belongs

12 Reporting guidelines used in GHG reporting

13 Assurance statement on disclosed information

14 Contact or responsible person for GHG reporting

15 Organization boundary and consolidation approach

16 Base year

17 Explanation for a change in base year

18 GHGs covered, including those not required by the Kyoto Protocol

19 Sources and sinks used/excluded

20 Conversion factors used/methodology used to measure or calculate emissions

21 Explanation for any changes to methodology or conversion factors previously used

22 A list of facilities included in the inventory for GHG emissions

23 Information on the quality of the inventory (e.g., causes and magnitude of uncertainties in estimates)

24 Information on any GHG sequestration

25 Disclosure of the supplier and the name of the purchased green tariff

26 Explanations for changes in performance of total $\mathrm{GHG}$ emissions in $\mathrm{CO}_{2}$ metric tonnes

27 Explanation of any country excluded, if global total is reported

28 Explanations for changes in performance of scope 1 emission 
1

2

3

4

5

6

7

8

9

10

29 Details of any specific exclusion of emissions from scope 1

30 Explanation for the reason for any exclusion from scope 1

31 Explanations for changes in performance of scope 2 emissions

32 Details of any specific exclusion of emissions from scope 2

33 Explanation for the reason for any exclusion from scope 2

34 Explanations for changes in performance of scope 3 emissions

\section{Quantitative disclosure}

35 Total GHG emissions in $\mathrm{CO}_{2}$ metric tonnes

36 Comparative data on total GHG emissions in $\mathrm{CO}_{2}$ metric tonnes

37 Future estimates of total $\mathrm{GHG}$ emissions in $\mathrm{CO}_{2}$ metric tonnes

38 GHG emission by business unit/type/country

39 GHG removals quantified in tonnes of $\mathrm{CO}_{2} \mathrm{e}$

$40 \quad$ Scope 1 emissions

41 Comparative data on scope 1 emissions

$42 \quad$ Future estimates of scope 1 emissions

43 Scope 2 emissions

44 Comparative data on scope 2 emissions

$45 \quad$ Future estimates of scope 2 emissions

$46 \quad$ Scope 3 emissions

47 Comparative data on scope 3 emissions

$48 \quad$ Future estimates of scope 3 emissions

49 Emission of direct $\mathrm{CO}_{2}$ reported separately from scopes

50 Emission not covered by the Kyoto Protocol and reported separately from scopes

51 Emission attributable to the firm's own generation of electricity/heat/steam sold or transferred to another organization

52 Emission attributable to the firm's own generation of electricity/heat/steam purchased for resale to end-users 
53 Reduction in tonnes of $\mathrm{CO}_{2} \mathrm{e}$ per year for purchased green tariff

$54 \quad$ Additional carbon saving associated with the tariff as a percentage

55 Quantitative data estimates of the regulatory risks as a result of climate change

56 Quantitative data estimates of all other risks as a result of climate change

57 GHG emission performance measurement against internal and external benchmarks, including ratios

$58 \quad$ GHG emission targets set and achieved

59 Information on GHG emission offsets

60 Comparative information on targets set and achieved 